一論 文—

\section{電流滴定法による天然水中微量塩化物イオンの化学増幅定量 ${ }^{122)}$}

（日本化学会誌，1985，(12)，p.2255～2259）

(C) 1985 The Chemical Society of Japan

\author{
（1985 年 4 月 15 日受理） \\ 作竹弘・池田早菃*
}

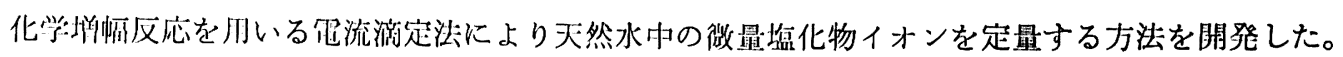

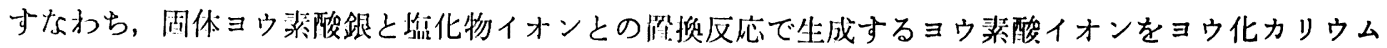
で雨流㵜定与る万法である。陚料 $15 \mathrm{~cm}^{3}$ 中 7 36 $\mu \mathrm{g}$ の塩化物イオンを $\pm 0.5 \mu \mathrm{g}$ 以内で定量するこ とができた。河川水, 非戸水拈よび雨水など然水中の塩化物イオンを定量したところ, 本法はチオシ アン酸水銀 (II) - 吸光光度法扣よびイオンクロマトグラフ法とよく一致する結果を与えた。固換反応は 約 $\mathrm{pH} 3$ の $60 \%$ メタノール溶液にヨウ装酸銀 $100 \mathrm{mg}$ を添加して行ならのが適当であった。生成す るョウ装酸イオンは回転白金電極（十0.7 V vs. SCE）を指示電極，SCE を対極とし， $2.5 \mathrm{~mol} ・ \mathrm{dm}^{-3}$ 硫酸基整液中でョウ化カリウム標淮液により滴定した。

木法は有㫪な水銀化合物を用いることなく，塩化物イオンをヨウ新酸イオンに㯰換することにより， 銀滴定法で困離な微量塩化物イオンを 5 倍に化学增幅して感度よく定量できるところに特徵がある。

\section{1 緒霉}

筀化物イオンは天然水中に広く存在して括り，一般河川水には

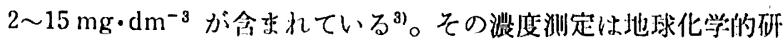

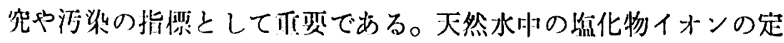

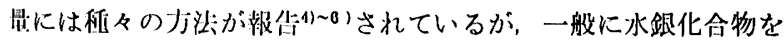

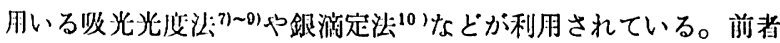
は水銀の有些性を考学ると好ましいう法でなく，後者は感度が少

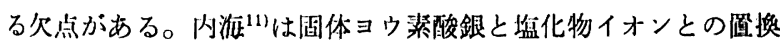
反忘を利用して，間接的に㙁化物イオンを农光光度法で分析する 方法を報告している。

ここで用いる反応は式( 1 )扰よび式 (2)に示与上うに，㙁化物 イオン $1 \mathrm{~mol}$ に刘してヨウ化物イオン $5 \mathrm{~mol}$ を必要とすることか

$$
\mathrm{AgIO}+\mathrm{Cl}^{-} \longrightarrow \mathrm{AgCl}+\mathrm{IO}_{3}^{-}
$$

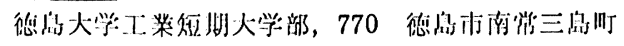

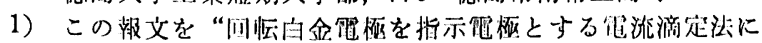
网与る分析化学的矿究(第 50 報)”と与る。

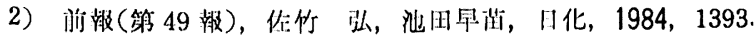

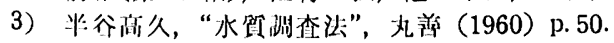

4) H. Akaiwa, H. Kawamoto, M. Osumi, Talanta, 29 , 689(1982).

5) G. Gran, A. Johansson, S. Johansson, Analyst, 106, 1109(1981).

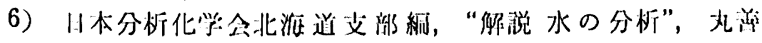
(1966) p. 147.

7) I. Iwasaki, S. Utsumi, T. Ozawa, Bull. Chem. Soc. $J$ Pn., 25, 226(1952).

8）淮: 唋, 11 化, 73, 835(1952).

9) JIS K 0101-1966.

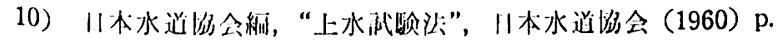
100.

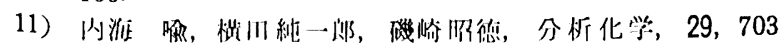
(1980).

$$
\mathrm{IO}_{3}^{-}+5 \mathrm{I}^{-}+6 \mathrm{H}^{+} \longrightarrow 3 \mathrm{I}_{2}+3 \mathrm{H}_{2} \mathrm{O}
$$

ら ${ }^{12)}$ ，辟换反応で生成するョウ素酸イオンをヨウ化物イオンで滴 定することにより；銀滴定の 5 倍に化学增幅 ${ }^{18144}$ して塩化物イオ ンを定船することになる。

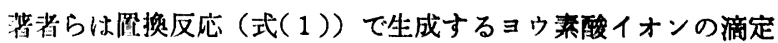
に禀感度電流滴定法を適用して，間接的に微量の塩化物イオンを 定胃する方法を梌尉し，各種天然水中の塩化物イオンの定量に応 用した。

\section{2 試菜，装而および英験方法}

\section{1 試 萧}

ヨウ絜酸銀 : $0.2 \mathrm{~mol} \cdot \mathrm{dm}^{-8}$ 硝酸銀と $0.2 \mathrm{~mol} \cdot \mathrm{dm}^{-3}$ ヨウ莱酸 カリウム各 $200 \mathrm{~cm}^{8}$ を調製し，前者を褐色ビュレット，後者を白 他ビュレットに入れる。蒸留水約 $200 \mathrm{~cm}^{3}$ 入れたビーカー $\left(1 \mathrm{dm}^{8}\right)$ に硝酸銀とヨウ絜酸カリウムをマグネチックスターラ 一でかさせぜながら約 $3 \mathrm{~cm}^{8} \cdot \mathrm{min}^{-1}$ の滴下速度で滴下してヨウ 慗酸銀を生成させる。㵜下後，十分かきまぜながら約 $50^{\circ} \mathrm{C}$ に加

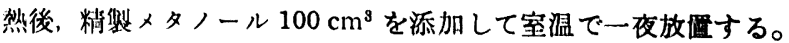
上澄み液を唅て，50\%メタノール $200 \mathrm{~cm}^{3}$ を加えてかきまぜた のち 10 㭙間消倾する。この操作を 4 回くり返したのち,ガラス 河過器 (1 G-S) を用いて吸引沪過する。令却した $50 \%$ メタノー ル $100 \mathrm{~cm}^{3}$ で沙浮後, 冷却した精製メタノール $200 \mathrm{~cm}^{3}$ で洗浄

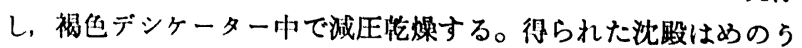
乳釗で粉挽し，裍色桼に保存して使用した。

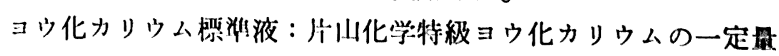
を水に楁解して $10^{-2} \mathrm{~mol} \cdot \mathrm{dm}^{-3}$ 溶液を調製し，銀滴定法（電位差 瀜定）により標定した。これを10 倍に希积して用いた。

12) R. Belcher, Talanta, 15, 357(1968).

13）池田早范，ふんせき，1979，329.

14）杉他純子, 池田早苗, 田中倩行, 日化, 1980, 1525. 
塩化ナトリウム摽淮液およびョウ素酸カリり人摽染液は和光純 薬の JIS 慓準試薬を用いて調製した。メタノールおよびエタノー ルは片山化学試楽一級メタノールおよびェタノールを1回蒸留し たものを用いた。での他の武浆はすべて特級品を用いた。なお沈 殿分離に用いた脱脂䄸は市販のものを蒸留水で十分洗浄し，精製 メタノールで洗浄後十分乾燥したものを用いた。

\section{2 装 量}

塩化物イオンとヨウ素酸銀の置換反応の温度設定には小松-大 和製 Coolnics Circulator CTR-1 B 型を用い，沈股分離には久保 田製作所製電気遠心沈殿機 K-8 型を使用.した。 $\mathrm{pH}$ は電気化学 計器社製 $\mathrm{pH}$ メーターIOC-10を, 吸光度は Bausch \& Lomb 社製分光光度計 Spectcronic 21 を用いて测定した。イオンクロ マトグラフは東洋曹達工業製 HLC-601 型を用いた。滴定装医は 既報13118)と同様なるのを使用した。

\section{3 分析操作}

A）塩化物イオンの定量 : メスフラスコ $\left(50 \mathrm{~cm}^{3}\right)$ に塩化物イ オン（2.4 mg 以下）を含む試料溶液 $15 \mathrm{~cm}^{3}$, 精製メタノール $30 \mathrm{~cm}^{3}$ および $0.05 \mathrm{~mol} \cdot \mathrm{dm}^{-3}$ 硫酸 $0.5 \mathrm{~cm}^{3}$ を正確にはかりと り，純水で全量を $50 \mathrm{~cm}^{3}$ とする。 $0^{\circ} \mathrm{C}$ でかきまぜながら 5 分経 過後, ヨウ素酸銀 $100 \mathrm{mg}$ を添加して 5 分間かきまぜる。試験管 $\left(20 \mathrm{~cm}^{3}\right)$ を少量の反応液で $2 \sim 3$ 回洗浄したのち，その $17 \sim 18$ $\mathrm{cm}^{3}$ を入れ，たたちに 30 秒間遠心分離 $(3000 \mathrm{rpm})$ する。つぎ に脱脂綿を上澄み液上に軽く二重に詰めて，脱脂綿が試䀫管の底 に沈むまで遠心分離（約 1 分間）する。滴定セル $\left(100 \mathrm{~cm}^{3}\right)$ に上 澄み液 $10 \mathrm{~cm}^{3}$ を正確にはかりとり, $5 \mathrm{~mol} \cdot \mathrm{dm}^{-3}$ 硫酸 $25 \mathrm{~cm}^{3}$ を 添加して水で全量を $50 \mathrm{~cm}^{3}$ とする。回転白金電極 $(+0.7 \mathrm{~V}$ vs. $\mathrm{SCE}$ )を指示電極, SCE を対極として, $10^{-3} \mathrm{~mol} \cdot \mathrm{dm}^{-3} ヨ$ ウ化力 リウム標準液を 5 秒ごとに $0.05 \mathrm{~cm}^{3}$ ずつ滴下して自動的に滴定 する。

B) 空試験值：空試験值 $\left(y \mathrm{~cm}^{3}\right)$ は A) で得られた滴定值を用 いて検量線法により求めた（図 3 参照）。

すなわち，塩化物イオンにより生成するヨウ素酸イオンと当量 のヨウ化カリウム標準夜の理論量 $\left(b \mathrm{~cm}^{3}\right)$ と, $10^{-4} \mathrm{~mol} \cdot \mathrm{dm}^{-3}$ 塩 化ナトリウム標準液 0 ～15 $\mathrm{cm}^{3}$ を用いて A) の方法で求めたヨウ 化カリウム標準液の消費量 $\left(a \mathrm{~cm}^{3}\right)$ を用いて， $1 / a$ を $X$ 軸に， $y(=a-b)$ を $Y$ 軸にプロットして検量線を作成した。

なお，!の值は本実験条件で塩化物イオンとヨウ素酸銀が定量 的に反応すると仮定した場合，ヨウ素酸銀の溶解によって消費さ れるョウ化カリウム標準夜量に相当する。

C）塩化物イオンの含有量：B）で求めた検量線式（6）を用い

て,A）の滴定值 $x \mathrm{~cm}^{3}$ より, 空試験值 $y \mathrm{~cm}^{3}$ を求めて, 式( 3 ) により塩化物イオン含有量を求めた。

$$
\mathrm{Cl}^{-}(\mu \mathrm{g})=7.09 \times 10^{3} \times C \times(x-y)
$$

なお，Cはヨウ化カリウム標準液の䀼度を示す。

\section{3 結果およひ考察}

\section{$3.1 \exists$ ヨ素酸イオンの滴定条件}

著者ら ${ }^{17)}$ はさきに回転白金電極（+0.7 V vs. SCE）を指示電

15) 佐竹 弘, 池田早苗, 分析化学, 28, 468(1979).

16）佐竹弘，池田早苗，日化，1984，1393.

17）佐竹 弘, 他田早苗, 田中雅美, 日化, 1981, 1260.

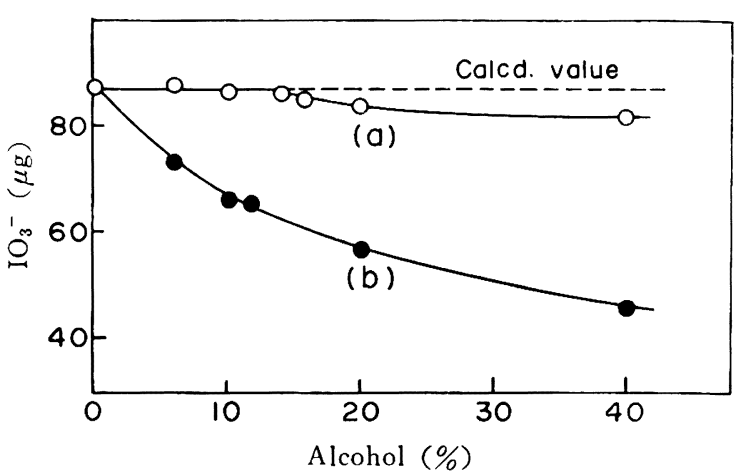

Fig. 1 Effect of alcohol on the determination of iodate ion

Sample solution $\left(50 \mathrm{~cm}^{3}\right)$ contains $25 \mathrm{~cm}^{3}$ of $10 \mathrm{~mol}$. $\mathrm{dm}^{-3} \mathrm{H}_{2} \mathrm{SO}_{4}, 5 \mathrm{~cm}^{3}$ of $10^{-4} \mathrm{~mol} \cdot \mathrm{dm}^{-3} \mathrm{KIO}_{3}$ and varying concentration of alcohol

(a) : Methanol, (b) : Ethanol

極, SCE を対極として, 低濃度の塩酸基礎液中でョウ素酸イオン をヨウ化カリウムで電流滴定する方法を報告した。今回は同様な 方法を用いて硫酸基礎液中で滴定する条件を検討したところ，最 終濃度が $2.5 \mathrm{~mol} \cdot \mathrm{dm}^{-3}$ 硫酸溶液中で逆 $\mathrm{L}$ 字型の明確な終点を示 す滴定曲線が得られることがわかった。また，置换反応において ヨウ素酸銀と塩化銀の溶解度を低下させるのに適当なアルコール 類の滴定への影饗についても検討した。図 1 に示すようにメタ, ールの場合には滴定時に $14 \%$ 程度存在しても影㗽は認められな かった。エタノールの場合には添加量が增加するにつれて分析値 が小さくなった。これは酸性溶液中でェタノールの一部がヨウ素 酸イオンと反応するためでないかと考えられる。

\section{2 沈殿 分離}

ヨウ素酸イオンをヨウ化カリウム標準液で滴定する場合, 被滴 定溶液にヨウ素酸銀および塩化銀の沈殷が共存するとヨウ化物イ オンと反応し（式(4)と（5))，大きな正の誤差を与える。

$$
\left.\begin{array}{l}
\mathrm{AgCl}+\mathrm{I}^{-} \longrightarrow \mathrm{AgI}+\mathrm{Cl}^{-} \\
\mathrm{AgIO}_{3}+\mathrm{I}^{-} \longrightarrow \mathrm{AgI}+\mathrm{IO}_{3}^{-} \\
\mathrm{IO}_{3}^{-}+6 \mathrm{H}^{+}+5 \mathrm{I}^{-} \longrightarrow 3 \mathrm{I}_{2}+3 \mathrm{H}_{2} \mathrm{O}
\end{array}\right\}
$$

そこで，2.3 と同様な方法でヨウ素酸銀と塩化物イオン $\left(10^{-4}\right.$ $\mathrm{mol} \cdot \mathrm{dm}^{-3}, 5 \mathrm{~cm}^{3}$ ) と反応させたのち，反応溶液中の未反応のヨ ウ素酸銀と生成する塩化銀を簡単かつ迅速に遠心分離する方法に ついて検尉した。

すなわち，反応液 $17 〜 18 \mathrm{~cm}^{3}$ を試験管にとり，ただちに 30 秒間遠心分離（3000 rpm） したのち，ピソセットで陚験管の器壁 との間にすきまがない上ら上澄み液上に軽く脱脂綿を詰め，さら にその上に前よりも少しきつく脱脂綿を融める。そして脱脂綿が 武験管の底に沈むまで遠心分滩与る(約 1 分閌)。その結果, 沈股 を3分以内で分離することができ，上澄み液の採取も容易とな り，安定した滴定線が得られることがわかった。なお，脱脂綿 を用いない場命には，上澄㕛液の採取眝に沈股が混入して，不安 定な滴定曲線を与えた。また，最初から顺北綿を街めて遠心分晟 した場合には，再胃性が悪くなる倾问を示した。 


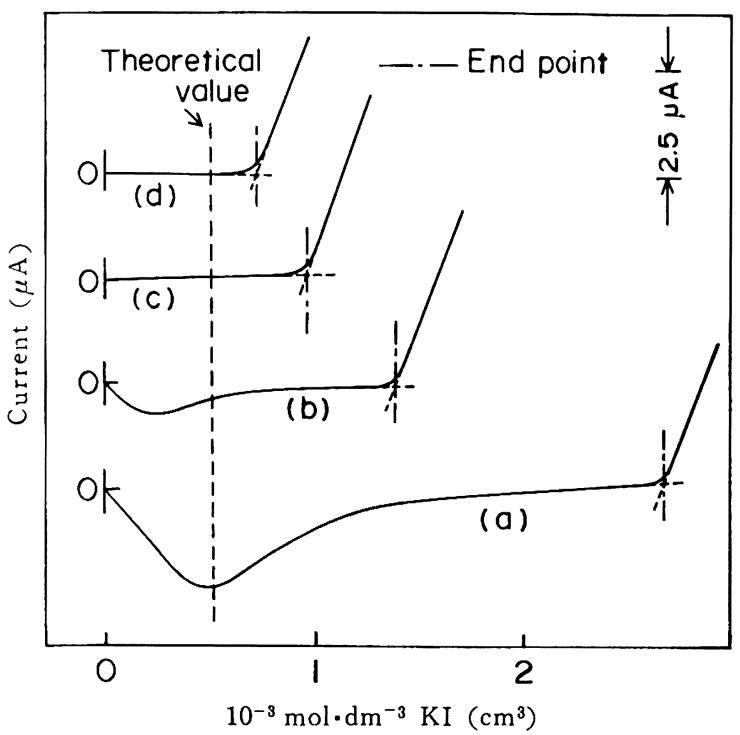

Fig. 2 Effect of methanol concentration on the replacement reaction of silver iodate and chloride ion

Conditions of replacement reaction : $10^{-4} \mathrm{~mol} \cdot \mathrm{dm}^{-3}$ $\mathrm{NaCl} ; 5 \mathrm{~cm}^{3}, 0.05 \mathrm{~mol} \cdot \mathrm{dm}^{-3} \mathrm{H}_{2} \mathrm{SO}_{4} ; 0.5 \mathrm{~cm}^{3}$, Methanol ; $x \mathrm{~cm}^{3}, \mathrm{H}_{2} \mathrm{O}$ (final volume $50 \mathrm{~cm}^{3}$ ), $\mathrm{AgIO}_{3} ; 100$ $\mathrm{mg}$, Temp ; $0^{\circ} \mathrm{C}$., Reaction time ; $5 \mathrm{~min}$.

Methanol: (a) ; $10 \mathrm{~cm}^{3}$ (20\%), (b) ; $20 \mathrm{~cm}^{3}$ (40\%), (c) ; $25 \mathrm{~cm}^{3}(50 \%)$, (d) ; $30 \mathrm{~cm}^{3}(60 \%)$

Conditions of titration : supernatant soln. ; $10 \mathrm{~cm}^{3}, 5$ $\mathrm{mol} \cdot \mathrm{dm}^{-3} \mathrm{H}_{2} \mathrm{SO}_{4} ; 25 \mathrm{~cm}^{3}, \mathrm{H}_{2} \mathrm{O} ; 15 \mathrm{~cm}^{3}$

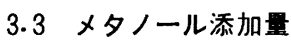

塩化物イオン $\left(10^{-4} \mathrm{~mol} \cdot \mathrm{dm}^{-3}, 5 \mathrm{~cm}^{3}\right)$ を用いて, メタノール 添加量の影響を検討したところ，眓2のよらな結果が得られた。

すなわち、メタノール濃度が低い場合はいちじるしく過大な滴 定值を与えるが，その濃度が高くなるにしたがって滴定值は理論 值に近接し，50\% 以上で安定した逆 L 字型の滴定曲線を与えた (図 2 の (c) と (d))。これはヨウ素酸銀および塩化銀の溶解度 が低下して，ヨウ素酸イオンの滴定に影響しなくなるためでない かと考えられる。40\% 以下では，ヨウ素酸銀などの溶解にともな って被滴定液中に存在する銀イオンやヨウ素酸イオン量が多くな り滴定值が大きくなる。一方滴定時に生成するヨウ素が銀イオン と反応して $\mathrm{AgI}_{2}{ }^{+}$のような銀-ヨウ素錯体を生成し，この還元電 流 $^{18)}$ が滴定初期に测定されるために，四 2 の（a）と（b）のよ らに不安定な滴定曲線となるものと考えられる。

以上のことから, 反応時の最終メタノール濃度が $50 \%$ 以上で 一定になるょう添加すればよいが，低濃度の塩化物イオンを定量 する場合には，陚料採取量を多くする必要がある。そこで本実験 では，ヨウ素酸銀の溶解によって消贸されるヨウ化カリウム標謴 液量が少なく，安定した湻定曲線が得られる $60 \%$ メタノール溶 液を用いることにした。

\section{4 ヨウ素酸銀添加量}

塩化物イオン $\left(18 / \mathrm{g} / 15 \mathrm{~cm}^{3}\right)$ を用いて，沙换反応に必要なヨ ウ素酸銀源加南について检封した。ヨウ素酸銀 50〜150 mg を添 加することにより一定した滴定值が得られた。また、ヨウ素酸銀

18) L. E. Edholm, Talanta, 25, 709(1976).
$100 \mathrm{mg}$ を用いた苆合には，7〜36 $\mu \mathrm{g}\left(15 \mathrm{~cm}^{3}\right.$ 中）の塩化物イオ ンが定量できることがわかった。なお，塩化物イオンとヨウ菜酸 銀はかきまぜながら 5 分以上反应させるのが通当であった。

\section{$3.5 \mathrm{pH}$ の影㸷}

塩化物イオン $\left(10^{-4} \mathrm{~mol} \cdot \mathrm{dm}^{-3}, 5 \mathrm{~cm}^{3}\right)$ とヨウ素酸銀 (100 mg) との膡換反応におよぼす $\mathrm{pH}$ の影䈏について検討した。

$\mathrm{pH} 6$ 以下では再現性のある分析值が得られたが，これ以上で は大きな值を示した。このことから，㽒換反応は $0.05 \mathrm{~mol} \cdot \mathrm{dm}^{-3}$ 硫酸 $0.5 \mathrm{~cm}^{3}$ を添加して $\mathrm{pH} 3$ 付近で行ならことにした。

\section{6 温度の影韧}

ヨウ素酸銀の溶解度はメタノール湿度や温度によって異なる。 また式(1)により生成するヨウ素酸イオン浱度が変わると, 共通 イオン効果によって溶液中の全ヨウ素酸イオン浱度が变化する。 このことから，微量の塩化物イオンを定量する場合には，ヨウ素 酸銀の溶解にともな5ヨウ化カリウム標準液の消費量（空試鍳 值）を求める必要がある。

そこで, $10^{-4} \mathrm{~mol} \cdot \mathrm{dm}^{-8}$ 塩化ナトリウム票準液 0 15 cm を用 いて， 2.3 と同様な方法で 0,10 およ゙ $20^{\circ} \mathrm{C}$ の各沮度における 滴定値と空試験值との関係を検討したところ, 図 3 のような結果 が得られた。

すなわち，各温度における空試験值と滴定值の逆数との間には 直線関係が認められた。このことから，20C 以下の一定温度では ヨウ化カリウム標準液の消費量から, 空試検値を求めることがで きることがわかった。また，温度が高くなると空試鍳值が，醏化 物イオンと反応して生成するョウ素酸イオンに対応するョウ化カ リウム標準液消費量よりはるかに大きくなり，微量の塩化物イオ ンを正確に定量することが困難になる。

以上の結果から，空試験值が小さく，かつ氷て容易に一定湜度 が得られる $0^{\circ} \mathrm{C}\left( \pm 0.2^{\circ} \mathrm{C}\right)$ で谪定することにした。

本実験条件を用いて，空試検值 $\left(y \mathrm{~cm}^{8}\right)$ と滴定值 $\left(x \mathrm{~cm}^{2}\right)$ との 関係を求めたところ，式(6)のような直線（相関係数 0.998）が 得られた。

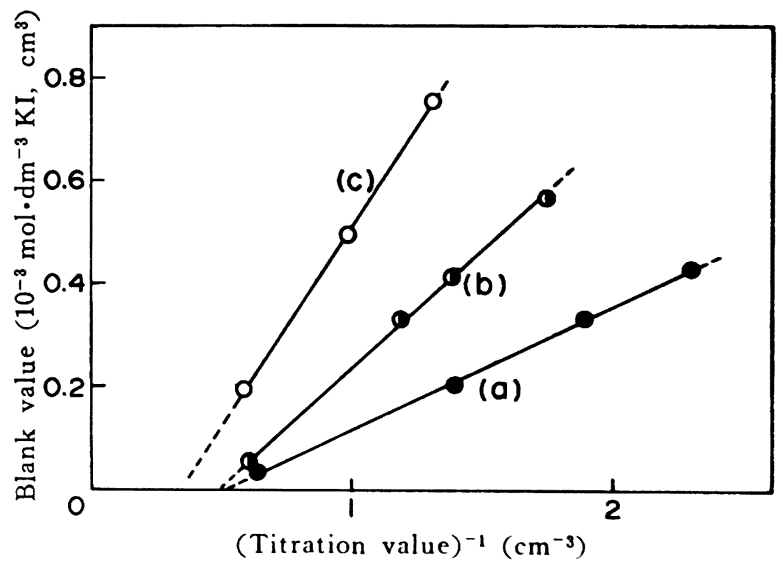

Fig. 3 Effect of temperature on the replacement reaction of silver iodate and chloride ion

Condition of replacement reaction is same as in Fig. 2 except for methanol $\left(30 \mathrm{~cm}^{3}\right)$ and temp.

Temp. $\left({ }^{\circ} \mathrm{C}\right):$ ( a ) : 0, (b) $; 10$, (c) $; 20$ Conditions of titration: Same as in Fig. 2 
Table 1 Effect of diverse ions on the determination of chloride ion

\begin{tabular}{|c|c|c|c|c|}
\hline \multicolumn{3}{|c|}{ Diverse ion } & \multirow{2}{*}{$\begin{array}{l}\text { Relative } \\
\text { error }(\%)\end{array}$} & \multirow{2}{*}{$\begin{array}{l}\text { Coefficient } \\
\text { of varia- } \\
\text { tion }(\%)\end{array}$} \\
\hline Ion & Compound & $(\mu \mathrm{g})$ & & \\
\hline $\mathrm{Ca}^{2+}$ & $\mathrm{CaSO}_{4}$ & 120 & -0.3 & 0.2 \\
\hline $\mathrm{Mg}^{2+}$ & $\mathrm{Mg}\left(\mathrm{NO}_{3}\right)_{2}$ & 97. & -0.6 & 0.6 \\
\hline $\mathrm{Fe}^{2+}$ & $\mathrm{FeSO}_{4}$ & 34 & -0.2 & 0.6 \\
\hline $\mathrm{NH}_{4}^{+}$ & $\mathrm{NH}_{4} \mathrm{NO}_{3}$ & 36 & +0.5 & 0.7 \\
\hline $\mathrm{CO}_{3}{ }^{2-}$ & $\mathrm{Na}_{2} \mathrm{CO}_{3}$ & 622 & +0.3 & 0.3 \\
\hline $\mathrm{F}^{-}$ & $\mathrm{NaF}$ & 37 & +0.5 & 1.0 \\
\hline $\mathrm{HPO}_{4}{ }^{2-}$ & $\mathrm{Na}_{2} \mathrm{HPO}_{4}$ & 36 & -1.0 & 0.5 \\
\hline $\mathrm{NO}_{2}^{-}$ & $\mathrm{NaNO}_{2}$ & 37 & -0.9 & 0.6 \\
\hline $\mathrm{SO}_{4}{ }^{2-}$ & $\mathrm{CaSO}_{4}$ & 864 & -0.3 & 0.2 \\
\hline
\end{tabular}

Sample : ca. $33 \mu \mathrm{g} \mathrm{Cl}^{-} / 10 \mathrm{~cm}^{3}$.

a) Average of four titrations.

$$
y=0.210+(0.220 \pm 0.02)(1 / x-1.31)
$$

なお，調製したヨウ素酸銀によって，空試験値の検量線が異な るので必要に応じて検量線を作成する。

\section{7 共存イオンの影䪪}

塩化物イオン $\left(33 \mu \mathrm{g} / 10 \mathrm{~cm}^{3}\right)$ を用いて，河川水に含まれる共 存イオンの影響について検討した。

表 1 に示すように, カルシウムイオン $(120 \mu \mathrm{g})$ ，炭酸イオン $(622 \mu \mathrm{g})$ ，マグネシウムイオン $(97 \mu \mathrm{g})$ および硫酸イオン（864 $\mu \mathrm{g} ）$ が共存しても $\pm 0.6 \%$ 以内の相対䛊差で定量することがで きた。等量程度の鉄(II)イオン，アンモニウムイオン，フッ化物 イオン, リン酸イオンおよび亜硝酸イオンなどが共存してもほと んど影響は認められなかった。なおョウ素酸銀と反応するような ヨウ化物イオン, 臭化物イオンおよび硫化物イオンなどや硫酸酸 性溶液中 (滴定時) でヨウ素酸イオンと反応するような還元性物 質は定量に影響するるのと考えられる。しかし，一般河川水や地 下水にはこれらは塩化物イオンにくらべて極微量しか共存しない のでそれらの影響は無視できるものと思われる。

\section{8 定量 結果}

本法により種々濃度の塩化物イオン溶液を定量した場合の $95 \%$ 信頼限界を表 2 に示す。

7 36 $\mu \mathrm{g}$ の塩化物イオンを $\pm 0.5 \mu \mathrm{g}$ 以内の誤差で定量するこ とがでさた。すなわち，試料溶液 $15 \mathrm{~cm}^{3}$ を用いるとすれば 0.5 $\sim 2.4 \mathrm{mg} \cdot \mathrm{dm}^{-3}$ の塩化物イオンの定量に応用できることが明ら かになった。 $3.3 \mathrm{mg} \cdot \mathrm{dm}^{-3}$ 以上の場合には空試験值も無視でき 簡単となるが，多量のヨウ素酸銀を必要とし，置換反応に長時間 を要するといら久点がある。このことから，本実験では $2.4 \mathrm{mg} \cdot$ $\mathrm{dm}^{-3}$ 以上の試料溶液の場合には，希釈するかあるいは塩化物イ
Table 2 Determination of chloride ion Chloride ion $(\mu \mathrm{g})$

\begin{tabular}{cr}
\hline Taken & \multicolumn{1}{c}{ Found } \\
\hline 7.1 & $7.1 \pm 0.5$ \\
17.7 & $17.7 \pm 0.2$ \\
28.4 & $28.9 \pm 0.0$ \\
35.5 & $35.5 \pm 0.4$ \\
71.0 & $70.4 \pm 0.5$
\end{tabular}

Sample solution : $15 \mathrm{~cm}^{3}$.

a) Average of four titrations.

Table 3 Analytical results of chloride ion concentration in natural waters

\begin{tabular}{|c|c|c|c|}
\hline \multirow{2}{*}{ Sample } & \multicolumn{3}{|c|}{$\begin{array}{l}\text { Chloride ion concentration } \\
\qquad\left(\mathrm{mg} \cdot \mathrm{dm}^{-3}\right)\end{array}$} \\
\hline & $\begin{array}{l}\text { JIS } \\
\text { method }^{a)}\end{array}$ & $\begin{array}{l}\text { Present } \\
\text { method }^{b 1}\end{array}$ & $\begin{array}{r}\text { Ion chromato- } \\
\text { graphycl }\end{array}$ \\
\hline $\begin{array}{l}\text { Rain water: } \\
\text { Tokushima-shi }\end{array}$ & $0.98 \pm 0.02$ & $1.1 \pm 0.2$ & - \\
\hline $\begin{array}{l}\text { River water: } \\
\text { Mt. Turugi }\end{array}$ & $1.60 \pm 0.02$ & $1.62 \pm 0.03$ & 1.69 \\
\hline $\begin{array}{l}\text { River water: } \\
\text { Naka gawa }\end{array}$ & $2.18 \pm 0.00$ & $2.18 \pm 0.02$ & 2.01 \\
\hline $\begin{array}{l}\text { River water: } \\
\text { Katsuura gawa }\end{array}$ & $4.35 \pm 0.06$ & $4.35 \pm 0.06$ & - \\
\hline $\begin{array}{l}\text { Mountain stream : } \\
\text { Katsuura gawa }\end{array}$ & $3.99 \pm 0.03$ & $4.00 \pm 0.2$ & 3. 60 \\
\hline $\begin{array}{l}\text { Well water : } \\
\text { Nakagawa }\end{array}$ & $20.9 \pm 0.2$ & $21.0 \pm 3$ & 20.8 \\
\hline $\begin{array}{l}\text { Well water: } \\
\text { Kawauchi }\end{array}$ & $202 \pm 3$ & $202 \pm 3$ & - \\
\hline $\begin{array}{l}\text { a) Average of } \mathrm{f} \\
b) \text { Average of } \mathrm{f}\end{array}$ & $\begin{array}{l}\text { e determir } \\
\text { ur titratio }\end{array}$ & ons. & \\
\hline c) Average of $t$ & & & \\
\hline
\end{tabular}

オンが $36 \mu \mathrm{g}$ 以下になるよう試料水を採取して定量することに した。

徳島県内の河川水, 井戸水および雨水中の塩化物イオンの定量 に本法を適用し，95\% 信頼限界とともに JIS 法およびイオンク ロマトグラフ法による分析值を比較して表 3 に示す。

本法は JIS 法（チオシアン酸水銀一吸光光度法）およびイオン クロマトグラフ法とよく一致する分析值を与え，天然水中の微量 塩化物イオンの定量に十分利用できることが確認された。

本法は有害な水銀化合物を用いることなく，比較的簡単な電流 滴定装置により微量の堭化物イオンを高感度に定量できるという 特徵がある。また他の銀イオンと沈殿反応与るイオンの微量分析 にも応用できるものと考えられる。 


\title{
Microdetermination of Chloride Ion in Natural Water by Amperometric Titration Using Chemical Amplification ${ }^{\dagger}$
}

\author{
Hiromu Satake and Sanae IKedA* \\ Technical College, The University of Tokushima; Minamijosanjima-cho, \\ Tokushima-shi 770 Japan
}

Chloride ion in natural water was replaced with solid silver iodate to iodate ion $\left(\mathrm{Cl}^{-}+\right.$ $\left.\mathrm{AgIO}_{3} \longrightarrow \mathrm{AgCl}+\mathrm{IO}_{3}{ }^{-}\right)$, which could be titrated with potassium iodide $\left(\mathrm{IO}_{3}{ }^{-}+5 \mathrm{I}^{-}+6 \mathrm{H}^{+} \longrightarrow\right.$ $3 \mathrm{I}_{2}+3 \mathrm{H}_{2} \mathrm{O}$ ) in the presence of sulfuric acid using a rotating platinum electrode (2000 rpm) at $+0.7 \mathrm{~V}$ vs. SCE. Error of less than $\pm 0.5 \mu \mathrm{g}$ was obtained with $7 \sim 36 \mu \mathrm{g}$ of chloride ion in $15 \mathrm{~cm}^{3}$ of sample. Analytical results of chloride ion $\left(1 \sim 202 \mu \mathrm{g} \mathrm{cm}^{-3}\right)$ in river, rain, and well waters by the proposed method showed good agreement with those obtained by the spectrophotometrical JIS method and ion chromatographical method.

The analytical procedure is as follows. Place exactly $15 \mathrm{~cm}^{3}$ of a sample containing chloride ion (less than $2.4 \mathrm{mg} \cdot \mathrm{dm}^{-3}$ ), $30 \mathrm{~cm}^{3}$ of methanol and $0.5 \mathrm{~cm}^{3}$ of $0.05 \mathrm{~mol} \cdot \mathrm{dm}^{-3}$ sulfuric acid in the volumetric flask $\left(50 \mathrm{~cm}^{3}\right)$ and make up the solution to the mark with pure water. After standing for about $5 \mathrm{~min}$ at $0^{\circ} \mathrm{C}$, add $100 \mathrm{mg}$ of silver iodate and stir for $5 \mathrm{~min}$. Transfer $17 \sim 18 \mathrm{~cm}^{3}$ of the solution into the test tube and immediately centrifuge for about $30 \mathrm{~s}$. Pack cotton fiber loosely on the surface of supernatant solution. Centrifuge once again until the cotton fiber sink down to the bottom of the test tube (about $1 \mathrm{~min}$ ). Place exactly $10 \mathrm{~cm}^{3}$ of supernatant solution in the titration cell $\left(100 \mathrm{~cm}^{3}\right)$. Add $25 \mathrm{~cm}^{3}$ of $5 \mathrm{~mol} \cdot \mathrm{dm}^{-3}$ sulfuric acid and make up to $50 \mathrm{~cm}^{3}$ with pure water. Titrate the resultant solution with standard potassium iodide solution amperometrically. Determine the blank value $(y)$ from titration value $(x)$ using a calibration curve (1) that is prepared with the solution of known chloride ion concentration in the same way as the sample. Estimate the concentration of chloride ion from the difference between titration and blank values.

$$
y=0.210+(0.220 \pm 0.02)(1 / x-1.31)
$$

$\dagger$ Studies on Analytical Methods by Amperometric Titration Using a Rotating Platinum Electrode. L. 